\title{
The COVID-19 Period: A Crisis for on-Site Learning or an Opportunity for Optimal Distance Learning? Examination of Student Attitudes
}

\author{
Miri Ben-Amram ${ }^{1} \&$ Nitza Davidovitch ${ }^{2}$ \\ ${ }^{1}$ Department of education, Ariel University, Israel \\ ${ }^{2}$ Head of the Ariel University Center's Unit of Academic Assessment and Development \& Head of the Israeli \\ Consortium of Faculty Development Centers, Ariel University, Israel
}

Correspondence: Nitza Davidovitch, Department of education, Ariel University, Israel. E-mail: d.nitza@ariel.ac.il

Received: February 15, 2021 Accepted: March 20, 2021 Online Published: April 6, 2021

doi:10.5539/jel.v10n3p27 URL: https://doi.org/10.5539/jel.v10n3p27

\begin{abstract}
This study, which explores student attitudes to online learning, is based on a psychoanalytic theory (Existence-relatedness-growth, ERG) on relatedness and growth, developed by American psychologist Clayton Alderfer. The purpose of the study was to examine whether online learning is merely a short-term temporary solution necessitated by the COVID-19 crisis, or will it enable a transformation of teaching and learning patterns in educational systems in the post-COVID era? What is students' personal preference regarding online learning after having inadvertently experienced it? What dimension of online teaching was meaningful for them: social presence, instructional-cognitive presence, emotional-personal presence? The research population consisted of 306 students, with a mean age of 15.5 . Only $85 \%$ of the students who participated in the study had technological resources for online learning at home. About $41 \%$ of the students preferred lessons that combine online teaching with frontal teaching in the classroom. In addition, the dimensions of online teaching reported by students as meaningful were, in descending order, social presence $(M=3.54)$, emotional-personal presence $(M=2.96)$, and instructional-cognitive presence $(M=2.73)$. The research findings might have an effect on policy makers in education with regard to maintaining an "innovative pedagogy" aimed at shaping students' image in order to prepare them for the new post-COVID era. In this period of global crisis, online learning afforded students innovative learning, where students enhanced their awareness of the significance of social presence, which was more meaningful than the dimension of instructional-cognitive presence. The significance of interpersonal interaction in teaching and learning received support, more so than ever before.
\end{abstract}

Keywords: COVID-19 crisis, distance learning, examination, student attitudes, social presence, instructional-cognitive presence, emotional-personal presence

\section{Introduction}

During March 2020 schools were closed and all "face-to-face" teaching in the educational system was halted in most countries around the world. According to UNESCO data, at the height of the crisis, in early April, 193 countries announced full closure of the educational system and about $90 \%$ of students worldwide stopped physical attendance of schools. Closing the schools has grave consequences for the students and their families, such as: disrupting the continuity of studies, a rise in school dropout; a rise in pressure and burnout among teaching staff; difficulties and disparities in the transition to distance learning and in the persistence in distance learning over time; disparities in parents' dealing with management of academic assignments and operating distance learning for their children; concern of rising exposure to violence and exploitation of children; harm to the development and well-being of children due to social isolation and challenges related to measurement and evaluation in education (Reimers \& Schleicher, 2020). In addition, there are severe consequences for the economy since the productivity of parents with young children is affected due to the need to supervise their children while the schools are closed. This situation might also result in harm to the healthcare system, which is affected by the absence of workers who have young school-aged children.

The preparation of Israel's educational system for distance learning stemmed from the mid-March government resolution to promptly close the schools, such that advanced technologies enabled distance learning but revealed essential difficulties, mainly in students' access to the necessary tools. Namely, distance learning intensified the 
digital gap between students from different socioeconomic groups and geographical areas (Weissblei, 2020).

During the COVID-19 period, when schools are closed and teaching is online, more students are marginalized: in $24 \%$ of Israeli households there is no internet, and $15.7 \%$ have no computer. Connection to the internet, as well as the availability of computers or other end devices, affect students' access to distance learning (Giannini \& Lewis, 2020; Schleicher, 2020). The transition to distance learning also revealed discrepancies in parents' ability to help students (GEM Report, 2020). Some researchers claimed that the significant role assumed by teachers teaching via distance learning was to help their students develop learning skills and strictly maintain contact with the students (Niwaz et al., 2019).

In these times students are required to adapt to leaning in a way that most of them were not previously familiar with, i.e., learning outside the school in a learning environment to which they were not accustomed and that includes the availability of study material on the web and is characterized by a minimal number of distractions (Miltiadou \& Savenye, 2003). The need to avoid distractions becomes even more significant in light of the fact that distance learning takes place in a technological environment, where use of technological means is sometimes detrimental to students' concentration and allows them to surf to other sites unrelated to the lesson (Manny-Iken et al., 2017). All this has become a challenge for teachers. Means that teachers can use for optimal learning include directing students to move to a comfortable and quiet location, letting students take short breaks throughout the day (Kelehear, 2020), and structuring a digital learning environment together with the students (Sharma et al., 2007), one that is as comfortable as possible for them considering the constraints of learning outside the school.

\section{Pedagogy in the Educational System and 21st Century Skills}

Preparing the graduates of the educational system for the demands of the future work world is a central national need and target in Israel. The skills currently required necessitate adaptation of the educational system by implementing optimal pedagogy in an environment based on information and communication technologies. Since 2010 a multiannual national ICT program called "Adapting the educational system to the 21 st century" has been implemented, and it encompasses $40 \%$ of Israel's schools. The program focuses on pedagogical organizational aspects and utilizes support and resources on the national systemic level and on the local level, with collaboration between the Ministry of Education, the local municipalities, and the schools. Initial evaluation of the program's efficacy indicates that use of ICT for learning purposes is on the rise and is showing considerable improvement compared to previous years" (National Authority for Measurement and Evaluation in Education [RAMA], 2013).

Technology creates new exciting learning situations and stimuli that are generated by the interaction between pedagogy and technologies (Fullan \& Langworthy, 2013). To date, however, it appears that the rapid rate of technological change does not match the ability of the educational system to adjust and to become swiftly updated. Hence, a disparity is formed between students' comportment in everyday life and the learning environments that schools offer them (OECD, 2014).

Assimilating technologies in schools is a long-term process that occurs only if a change has been effected in systemic and personal features such as: an educational vision that supports the school culture (Ertmer \& Ottenbreit-Leftwich, 2010), a strong, professional, and supportive teacher community (Shamir-Inbal \& Avidov-Ungar, 2013), perception of the teacher's essential role in the classroom as a colleague and partner in the learning process, and the teacher's pedagogical-technological self-efficacy (Blau \& Shamir-Inbal, 2017).

\subsection{The Effects of Online Learning on Learning at School: Cognitive and Emotional Aspects}

Online learning is an inseparable part of school teaching and learning during the COVID-19 pandemic. This fact indicates the need to emphasize teaching methods, quality, and design adapted to the various learners in order to generate success among learners (Guo et al., 2016). The research literature shows that features of online learning such as shaping instruction, interaction, cooperation, methods, and shaping online teaching and learning environments have a considerable contribution to adapting teaching and learning to the various learners, which encourages use of a variety of models in order to implement constructivist teaching methods (de Freitas \& Oliver, 2005; Weller, 2011). All these support cooperative activities and a variety of teaching methods. Side by side with the wealth of activities possible on the internet, there are also personal learning processes (Oliveira et al., 2019). The variety of pedagogic applications is wide and teachers mostly require direction in order to choose the tools and generate optimal pedagogic applications. Among the features that help reach successful online lessons are communication skills and interpersonal skills, understanding and appreciation of interaction and cooperative learning, as well as self-efficacy among all participants in the lesson (Stöter et al., 2014). 


\subsection{The Role of the Reacher in Online Learning}

In online learning the teacher's role varies and a considerable part of the responsibility for gathering information, evaluating sources, forming ideas, and presenting them while learning is transferred to the learners (Kop et al., 2011). The teachers become knowledge curators, guides, facilitators, supporters, learners, and information sharers (Martin et al., 2019). In this changing reality, it is important to focus on creating a learning environment that encourages interpersonal connections and learning experiences that have value for the learners (Shedroff, 2009). The teachers are required to maintain tight structuring of the lesson's contents while giving learners room for action, facilitating work on authentic tasks, varying contents and sources while maintaining the quality of materials, empowering the students' ability to manage learning, providing feedback in a reasonable time frame, encouraging as much personal communication as possible, and maintaining regular weekly personal contact with students (Tang et al., 2016). Most of the teachers report that they have the necessary equipment and infrastructure to carry out distance teaching. In addition, many teachers report that schools do not have the necessary peripheral equipment (headphones, cameras, printers, etc.), and some expressed anger at being expected to supplement this equipment from their private sources. Most of the teachers reported that they have lesson plans and teaching units, digital pedagogic materials, tools for managing learning, and knowledge in operating online systems. Nonetheless, it is notable that high school teachers reported a lack of high-quality online digital materials for the secondary age level and that they must produce or locate suitable materials (Blass \& Bleikh, 2020).

\subsection{Online Teaching and lLearning Processes}

During the COVID-19 period, it seemed that there was an attempt to emulate (frontal) classroom teaching in distance learning. However, distance teaching and learning are not synchronous online lessons. Distance teaching and learning include other components such as independent learning by students, group learning, and encounters of the teacher with groups of students, not necessarily in a whole-class format. According to a Ministry of Education report (RAMA, 2020) the optimal format for online encounters by teachers is with groups of students (for instance by ability, by field of interest), side by side with a great deal of independent work by students in teams. To this should be added operations intended to examine students' achievements, relief activities, and personal encounters with students. Encounters that utilize a format of the teacher with the entire class should be relatively infrequent (RAMA, 2020). In addition, there are difficulties since the manner of communication between the teacher and students and between the teacher and colleagues has changed because communication via digital media reduces facial expressions, eye contact, body posture, and tone of speech, which regulate interaction processes. In addition, some claim that it is hard for distance encounters between teachers and students to generate meaningful learning. Many students do not feel connected to online sessions or do not carry out online tasks and are therefore excluded from the learning circle, whereby the teachers' ability to evaluate the quality of learning is also hampered.

However, when performed adequately distance learning and teaching have many important benefits both in times of emergency and in routine. In times of emergency, when there is a need to close the schools, they provide a response to one of the school's important roles - imparting knowledge and academic skills (Weissblei, 2020). In times of routine, they can constitute an important and central part of the student's training to perform independent learning, take personal responsibility, and form direct relationships with teachers. Other unique features of the online environment are the ability to maintain asynchronous and non-linear activities, flexible time, the lack of a defined location for participating in learning when students are in diverse learning environments, the ability to manage the classroom, and the possibility to give learners more independence. These unique features constitute an opportunity for teaching that enables a personal learning pace, the ability to study thoroughly, connecting the study material to everyday life, autonomous learning, and expanding one's perspective following exposure to multiple opinions in the online community.

\subsection{The Existence-Relatedness-Growth (ERG) Theory}

The existence-relatedness-growth (ERG) theory is a psychoanalytic theory developed by American psychologist Clayton Alderfer. This theory is in fact a reformulation of Abraham Maslow's theory of needs. According to this theory, the needs are divided into three divisions rather than the five suggested by Maslow. Similar to Maslow's theory, satisfying one level of needs advances one towards satisfying the highest level of needs. But Alderfer also identifies a reverse process. According to the new theory, there is also a process of frustration stemming from the lack of ability to realize a certain level of needs. This frustration leads one to retreat to the attempt to provide a lower level of needs (Alderfer, 1969). This theory does not involve a "personality hierarchy" but rather three groups of needs that operate differently. Alderfer criticizes the direct association that Maslow assumes 
between the urge to provide a need and motivation. The three groups of needs do not operate in a strictly hierarchical manner. A person might engage concurrently in satisfying needs from different groups:

1) Existence needs - physiological needs and security needs.

2) Relatedness needs - the need for social approval.

3) Growth needs - the need to develop personal skills that constitute a relative strength versus other individuals.

\subsection{The Three-Dimension Model of Effective Online Learning}

Researchers assume that learning that occurs in an online lesson through interaction between a teacher and students has three main elements: social presence, instructional-cognitive presence, and personal-emotional presence (Garrison et al., 1999).

The term "social presence" is defined as the ability of participants in an online lesson to act in favor of interpersonal interactions with the aim of presenting their personal traits to the other participants. Garrison et al. (1999) claim that social presence contributes directly to the success of the educational experience, since cooperative communication is important for building meaningful optimal shared knowledge. Cooperation is perceived as an essential aspect of cognitive development, as cognition cannot be separated from social context. Salmon (2003) claims that when beginning e-learning it is necessary to develop a process of socialization among the learners, to encourage them to send messages to each other and to establish their identity on the web. This stage is vital for establishing efficient teaching/learning further on. Moreover, her study found that the interactivity between the learners increases and intensifies with the progress of the online lesson.

The term instructional-cognitive presence is a vital component of critical thinking that presents the student's ability to understand the lesson in an interesting, neat, and organized way, while improving learning and teaching skills. Lipman (1995) notes the significance of cooperation by all participants during the lesson, with the goal being to develop higher-order thinking such as critical thinking comprised of questioning, justification, connection, deliberation, and developing problem solving techniques. Garrison et al. (1999) relate to this as a cooperative constructivist perspective on teaching and learning. This perspective sees the educational experience as a process of cooperative communication with the aim of building significant knowledge.

The term personal emotional presence relates to the meaning of the student's physical and emotional comfort during the lesson.

\subsection{The Constructivist Approach and Meaningful Online Learning}

The constructivist approach is based on the perception of learning not as a passive process but rather as a personal active process wherein each learner actively processes and interprets the content absorbed, searches for the main occurrences within it, tries to understand it in context and to give it meaning (Schauble et al., 1993). In the learning process the learner is in the center, but mutual relations with the environment are essential. In the teaching process, nurturing thinking skills, searching for information, managing and processing information, are emphasized, while increasing meta-cognitive awareness to regulate and direct the learning process, in the understanding that the student evolves and is developed through social-cultural mediation (Shachar, 2011). Constructivist teaching includes the components for creating a learning space that has a teacher-student-material discourse; stressing the authenticity of the contents and topics and their relevance for the learner's life; anchoring learning activities in complex assignments, problems, and dilemmas; structuring learning around core concepts. In this method of teaching the teachers put their trust in the students, in the assumption that all the students are capable of learning and of reaching the necessary achievements (Vygotsky, 1978). Hence, the teaching espouses not only changing learners' behaviors or acquiring skills, rather its main intention is to bring them to intensive comprehension of the studied material. A learning environment based on the constructivist approach is characterized by interactions between teachers and students and among students themselves around the content in a certain context. The quality of these processes affects students' achievements (Darling-Hammond \& Youngs, 2002). This means that the expectation of a learning environment that combines varied digital technologies is to implement learning methods directed at developing skills and experiencing research processes and problem solving, to assume responsibility, and cooperation that requires interaction and mediation (Ertmer \& Ottenbreit-Leftwich, 2010). The technological abilities of gathering information, management, producing information, and sharing information make it possible to realize many opportunities of innovative constructivist learning (Mikropoulos \& Natsis, 2011), in which students are involved and active partners in the learning process. Therefore, the teacher-student relationship is manifested in how the teacher is perceived as a mediator of learning who leads the learner to significant learning (Libman, 2013).

The term "innovative pedagogy" describes teaching, learning, and evaluation in new approaches that reflect the 
constructivist approach (Mioduser et al., 2003). This pedagogy changes the traditional teaching model where "knowledge is conveyed" from the teacher to the students, to teaching that encourages structuring of knowledge by the students themselves (Blau \& Peled, 2012). Innovative pedagogy redefines the goals of education, the student's image, and the skills that should be developed in students in order to adapt them to the 21st century, skills that focus on three main areas: higher-order thinking, cooperative work, and managing digital information (Vidislavsky et al., 2010).

\subsection{Student Attitudes Towards Online Learning}

Different students have different attitudes to learning in an online environment: elementary and junior high school students have an interest and wish to study in such an environment; they enjoy learning in this way and perceive ICT as capable of advancing learning (Kelly, 2011). In contrast, some high school students have a negative attitude. They perceive online learning as weakening, reducing their learning skills, enabling simple shortcuts, and encouraging laziness (Ben David Kolikant, 2019). In addition, some high school students have a neutral attitude to learning in an online environment: they do not recognize its strengths but neither do they object to it (Tovi, 2002). Students' attitudes towards ICT in the educational system affect its assimilation and the extent of its use. Hence, students who have a positive attitude towards online learning will often use technologies in learning (Kozma, 2003; Turuthi et al., 2017). While online learning, as a component of the "internet culture", is flexible and open to change, the encounter between the traditional learning environment at the school and the online learning environment is detrimental to the effectiveness of learning. In addition, the results of their research (Moreno-Guerrero at al., 2020) show that, the use of the e-learning method has a positive influence on motivation, autonomy, participation, and grades. It can be concluded that the e-learning method leads to improvement in students.

In summary, according to the constructivist approach to meaningful learning, Alderfer's (1969) model, and Vaughan and Garrison's (2006) theory, optimal online teaching has three dimensions: Social presence: interactions with students and teachers; instructional-cognitive presence: improving learning abilities in online teaching, teacher availability, improving teaching ability-interest, order, and organization, and clarity; and the dimension of the student's personal-emotional presence: personal preference of the student, comfort in the online learning process, and sparing resources. Based on the literature, the balance between the three interactions, social, instructional-cognitive, and personal-emotional presence, is vital for optimal learning in order to build group cohesiveness in a respectful lesson and group discourse. Richardson and Swan (2003) identified an association between social presence and cognitive teaching; students who perceived high social presence studied more efficiently than those who perceived low social presence. In addition, some students are focused on their studies and do not need or want to deal with a virtual social space (McPherson \& Nunes, 2004). The researchers claimed that the stronger the social presence, i.e., if there is a sense of a common goal in the lesson, the higher the instructional-cognitive presence. These educational challenges raise the significance and role of the teacher's and students' presence in teaching. Therefore, instructional-cognitive presence must take into consideration the double role of social presence and personal-emotional presence, as they are both vital for successful online learning.

Based on this theory, the research hypotheses were constructed:

1) Students will prefer combined learning, namely online teaching together with frontal teaching in the classroom, after the COVID-19 pandemic ends.

2) No differences will be found in students' attitudes to online learning on the three dimensions: social presence, instructional-cognitive presence, and personal-emotional presence.

\section{Research Method}

\subsection{Research Tools}

The research model was built according to the Vaughan and Garrison's theory (2006) and Alderfer's theory (1969). This model presents the tangential categories between the model and theory of optimal online teaching:

1) Relatedness needs, including social presence and interactions with students and teachers.

2) Personal growth needs, including instructional cognitive presence and attitudes towards improving learning abilities in online teaching, teacher availability, improving teaching ability-interest, order, and organization, and lesson clarity.

3) Physical existence needs: with the dimension of personal emotional presence, including personal preferences of the student, comfort in the online learning process, and sparing resources. 
The questionnaire presented to the respondent's statements related to the effect of online learning on the quality of learning, identifying its strengths and weaknesses. The students were asked to rank their replies on a scale of 1 to 5 (where 1 ins not at all and 5 is very much). For the purpose of the study a questionnaire was developed, comprised of 11 measures that include 50 statements.

\subsection{Research Procedure}

The questionnaire was constructed online and posted on the internet, from where it was shared in online groups of students around the country.

\subsection{Research Population}

The study participants included 306 students with a mean age of 15.5, 134 male students who constituted 44\% and 172 female students who constituted $56 \%$ of all participants. Thirty-eight students were in elementary school, constituting $12.4 \%$ of all participants. Ninety-seven of the students were in junior high school, constituting $31.6 \%$ of all participants; and 171 were in high school and constituted $55.9 \%$ of all participants.

\subsection{Research Results}

The following are tables with the students' background data:

Table 1. Existence of technological resources for online learning in the student's home

\begin{tabular}{lll}
\hline Existence of technological resources for online learning & Quantity & Percentage \\
\hline Exist & 259 & 84.6 \\
Do not exist & 47 & 15.4 \\
Total & 306 & 100 \\
\hline
\end{tabular}

Table 1 shows that $85 \%$ of the students who participated in the study have the necessary technological resources for studying at home, such as a computer, an internet connection, and end devices: A Tablet, a mobile phone. Also, $15 \%$ of students do not have the technological resources for online learning.

Table 2. Type of lesson preferred by the students.

\begin{tabular}{lll}
\hline Type of lesson & Quantity & Percentage \\
\hline Synchronous lesson & 96 & 31.4 \\
Asynchronous lesson & 84 & 27.5 \\
Combined lesson & 126 & 41.2 \\
Total & 306 & 100 \\
\hline
\end{tabular}

Table 2 shows that most of the students (41\%) chose the combined lesson as the preferred lesson, namely a lesson that combines a distance online lesson and a frontal lesson at school is preferred by the students who participated in the study.

Table 3. The research categories and measures

\begin{tabular}{|c|c|c|c|c|}
\hline Category & Dimension & $\begin{array}{l}\text { Cronbach's } \\
\text { alpha reliability }\end{array}$ & $\begin{array}{l}\text { Standard } \\
\text { deviation }\end{array}$ & Mean \\
\hline Social presence & Interactions with students and teachers & .76 & 0.95 & 3.54 \\
\hline Instructional-cognitive presence & Improving study abilities in online teaching & .88 & 0.92 & 2.74 \\
\hline Instructional-cognitive presence & Teacher availability & .60 & 1.09 & 2.82 \\
\hline Instructional cognitive presence & Improving teaching ability & .88 & 0.92 & 2.74 \\
\hline Instructional cognitive presence & Improving teaching - clarity & .92 & 1.17 & 2.61 \\
\hline Instructional cognitive presence & Improving teaching - interest & .79 & 0.99 & 2.73 \\
\hline Instructional cognitive presence & Improving teaching - order and organization & .88 & 1.16 & 2.74 \\
\hline Personal-emotional presence & Personal preference by the student & .77 & 0.95 & 2.60 \\
\hline Personal-emotional presence & Comfort in the online learning process & .60 & 0.75 & 2.89 \\
\hline Personal-emotional presence & Sparing resources & .70 & 1.41 & 3.40 \\
\hline
\end{tabular}

Table 3 presents the distribution of means for students' attitudes to online teaching by the four categories and associated dimensions in a descending order: social presence $(\boldsymbol{M}=3.54)$, personal-emotional presence $(\boldsymbol{M}=$ 
2.96), and instructional-cognitive presence $(\boldsymbol{M}=\mathbf{2 . 7 3})$. Figure 1 presents the means for student attitudes to online learning by the appropriate categories and dimensions.

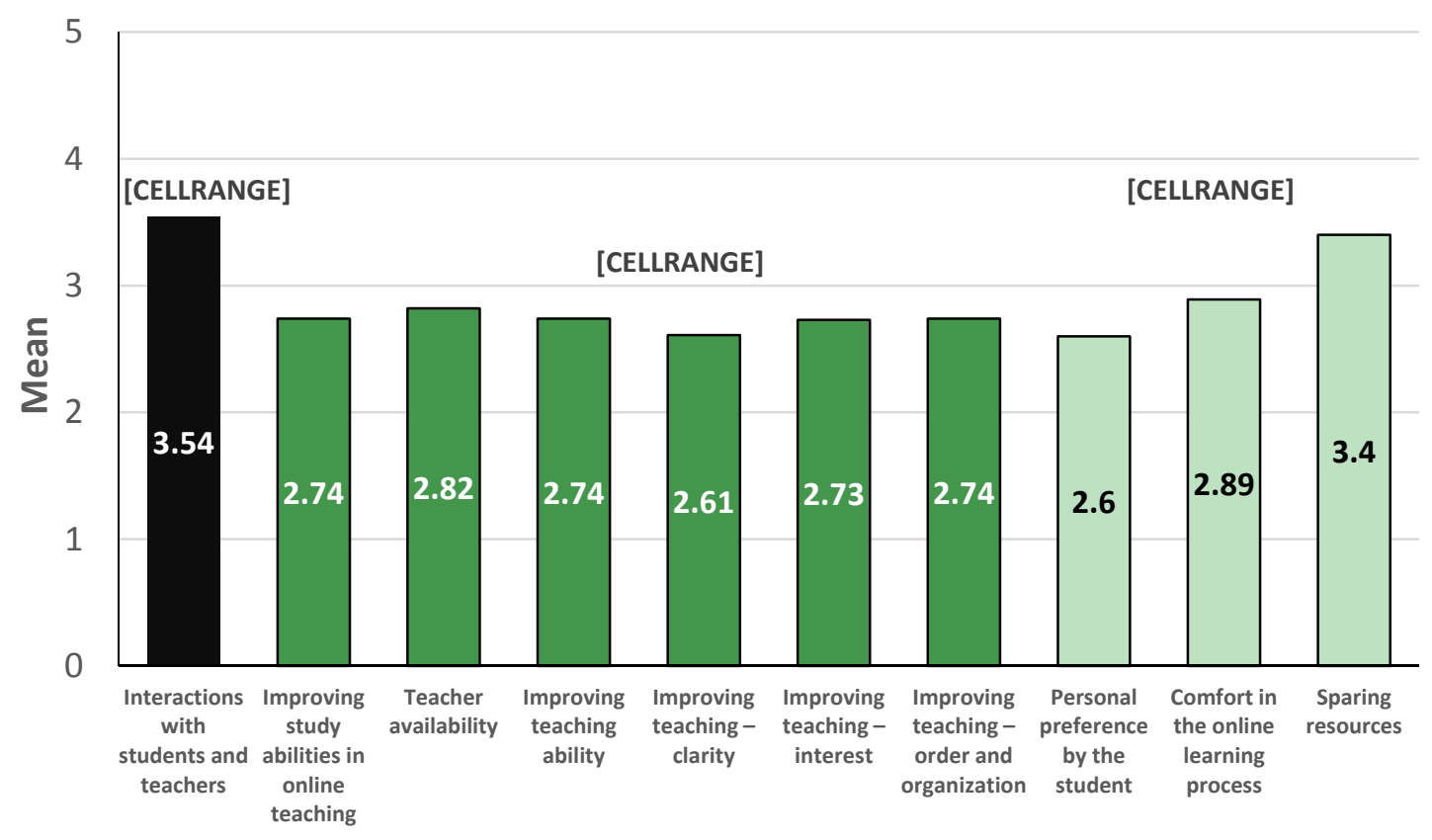

\section{Dimensions}

Figure 1. Means for students' attitudes to online teaching

This figure presents the three measures examined. The most significant dimension was that of social presence, namely the personal interactions between students and teachers and between students and their classmates. The next dimension to receive high mean values was that of personal-emotional presence, namely the student's comfort in the online learning process. The last dimension was instructional-cognitive presence, namely in the online learning process the lesson is given with much interest, there is order and organization, and it is more focused, and the student feels an improvement in his study ability.

\section{Summary and Discussion}

The period of the COVID-19 pandemic posed challenges for the educational system in Israel and elsewhere, with regard to the transition to online learning in a short span of time and with no advance preparation. Israel's Ministry of Education, including the Office of the Chief Scientist, responded to this challenge with the aim of formulating, through academic committees, documents that would support the system in handling fundamental issues underlying online learning and teaching.

The main purpose of the current study was to examine whether online learning was a short-time temporary solution or whether there is a real chance that distance teaching and learning will become a means of teaching after the COVID era as well, as an inseparable part of the new routine. The finding regarding students' personal preference regarding online learning was that $41 \%$ of the students who participated in the study preferred "combined lessons", namely lessons that combine online teaching and frontal classroom teaching, with each type of teaching having its strengths and weaknesses. For example, on one hand online learning spares resources and preparations for the trip to school, and on the other the students expressed a concern that this type of learning might affect their grades in the report card as it is hard for them to concentrate. Then again, on one hand frontal learning creates effective interaction between the students and the teachers and among the students in the classroom. On the other, in online learning there is a larger array of digital means used. Therefore, the combination between the two types of lessons, the frontal lesson and the online lesson, namely "combined learning", is very effective as it manages to create a large number of benefits for the student.

Another aim of the study was to check which of the three dimensions that exist in online teaching according to 
the theory of Vaughan and Garrison (2006): social presence, instructional-cognitive presence, and personal emotional presence, were the most dominant among students in online learning, as based on the ERG theory that presents the three dimensions of existence-relatedness-growth (Alderfer, 1969). The finding analysis showed that the dimension of "social presence", including personal interactions between students and teachers and between students and their classmates, had the highest mean. During the COVID-19 pandemic, students feel very lonely as they do not attend school and are at home for many hours facing the computer screen. In addition, even informal education by youth movements has moved online, so the students do not see their friends, neither in the morning at school nor in the afternoon in youth movements or after-school classes, so the social dimension exists only in the digital sphere and it was very important and essential for the students. The dimension of personal-emotional presence checked the student's comfort in the online learning process, for instance: in an online lesson the student can move at will around the room without disturbing his classmates, he can dress as he likes as there is no requirement to wear a school uniform, he does not need to prepare for the trip and waste lots of time on the way to and from school. Therefore, students' grades improved because their quality of live improved following online learning. And finally, the dimension of instructional-cognitive presence. Students noted that the transition to online teaching improved their learning ability as they were not exposed to distractions and the proper procedure of the lesson is not disrupted by other students. This state of affairs may have caused an improvement in students' concentration during the online lesson. Moreover, students noted that it is easier to make up study material since the lesson is recorded and that they speak up more during online lessons than in frontal lessons. Also, the teacher "sees them", as other students do not block them as in the classroom. In online learning each student has a picture with his name. In addition, the students noted the availability of the teachers in the online lesson, namely the teacher is more responsive to student questions as they are quieter and more attentive. In addition, there are other communication channels in the lesson, such as the chat during the lesson, and via e-mail. Also, the students noted that in the online learning process the lesson taught is more interesting and passes quickly. At the same time, the students noted that in online teaching there is more order and organization and it is more focused. There is a detailed explanation of the lesson's development, there is a logical sequence, and there are no associative jumps from topic to topic during the lesson. The teacher presents links to videoclips and the learning is clearer and more lucid. In addition, in online learning there is no bell and breaks during the day are taken at the student's home, at the end of the online lesson. The daily study schedule was reduced during the COVID-19 pandemic in order to avoid overburdening the students. Therefore, continuing Alderfer's (1969) theory that represents the three dimensions of existence-relatedness-growth, which claims that the three needs are not satisfied according to the hierarchical order as in Maslow's theory of needs, rather one may engage concurrently in satisfying needs from different groups of needs, in the research findings students' attitudes showed that the dimension of relatedness, i.e., "social presence", is the most dominant, followed by the dimension of physical existence needs, i.e., personal-emotional presence, and finally the dimension of personal growth needs, i.e., "instructional cognitive presence". A possible explanation for this is the age of the research participants, who were in the middle of adolescence, at age 15.5. Also, the Ministry of Education may have assumed that the schools would be closed during the COVID-19 pandemic and therefore the online schedule created a type of "safe" space in the lesson, where students could meet their classmates all together without breaching the lockdown instructions, such that the dimension of relatedness was higher, as noted by the students.

In summary, Winston Churchill said "never waste a good crisis", so the recommendation of the study is that after the global pandemic ends and the teachers and students return to school, teachers should combine online lessons one day a week, in addition to frontal lessons at school, since distance learning poses difficulties for the learning process as the home environment is not appropriate for learning (distractions, noise, difficulty getting organized). In addition, it is hard to maintain concentration over time, particularly due to the lengthy time spent facing the screen. It is difficult to identify students' level of understanding and to locate students who need added clarifications during the lesson. The challenge of maintaining students' attention is much harder in online learning, therefore it is necessary to combine screen activity and active deeds, while shortening screen activity. It is necessary to monitor students' emotional and mental state and to find technological solutions that facilitate connections, interaction, and active support while studying. Teachers can enhance internal motivation to learn by presenting authentic tasks related to students' everyday life. Teachers can enhance students' self-efficacy by providing positive feedback (Cho \& Shen, 2013). Experience in many countries, even those that had more success with online learning, indicates that the approach should be based on the assumption that online technology completes and reinforces teaching and learning but cannot replace the teachers. Students require teachers to act as homeroom teachers/facilitators/coaches in order to direct and guide them, check assignments, with the aim of locating struggling students and encouraging them. All this necessitates teachers who have strong 
emotional and social skills and also technological literacy and the ability to operate in a new technological environment. In addition, it is necessary to check and consider parents' involvement and cooperation with distance learning at home with the students. The Knesset report based on data from the Central Bureau of Statistics indicates gaps involving lack of access to digital infrastructure among extensive parts of the population. About $24 \%$ of households with children in Israel have no internet access and $7.15 \%$ of households have no personal computer. Therefore, the recommendations of the study for the educational system are to provide computers and internet infrastructure to weakened populations in order to reduce the digital gap. On the national level, forming an organizational infrastructure that supports online learning by training the teaching staff to prepare effective and high-quality online study materials, methods of giving lessons, and evaluation of achievements, including pedagogical and technical assistance. In addition, creating a high-quality reservoir of digital learning materials to be used by teachers and learners.

\section{References}

Alderfer, C. P. (1969). An empirical test of a new theory of human needs. Organizational Behavior and Human Performance, 4(2), 142-175. https://doi.org/10.1016/0030-5073(69)90004-X

Ben-David, K. Y. (2019). Adapting school to the twenty-first century: Educators' perspectives. Technology, Pedagogy and Education, 28(3), 287-299. https://doi.org/10.1080/1475939X.2019.1584580

Blass, N., \& Bleikh, H. (2020). Expenditure per class and student in the primary education system. Taub Center. Retrieved from http://taubcenter.org.il/wp-content/files_mf/expenditureinprimaryschoolsystemeng.pdf

Blau, I., \& Peled, Y. (2012). Are teachers open to change? Laptop per teacher, laptop per student—Preliminary results of a comparative study. In Y. Eshet-Alkalai, A. Caspi, S. Eden, N. Geri, Y. Yair \& Y. Kalman (Eds.), Proceedings of the Chais conference on instructional technologies research 2012: Learning in the technological era (pp. 35-44). The Open University of Israel [in Hebrew]. Retrieved from http://www.openu.ac.il/innovation/chais2012/downloads/e-28.pdf

Blau, I., \& Shamir-Inbal, T. (2017). Digital competences and long-term ICT integration in school culture: The perspective of elementary school leaders. Education and Information Technologies, 22(3), 769-787. https://doi.org/10.1007/s10639-015-9456-7

Cho, M.-H., \& Shen, D. (2013). Self-regulation in online learning. Distance Education, 34(3), 290-301. https://doi.org/10.1080/01587919.2013.835770

Darling-Hammond, L., \& Youngs, P. (2002). Defining "highly qualified teachers": What does "scientifically-based research" actually tell us? Educational Researcher, 31(9), 13-25. https://doi.org/10.3102/0013189X031009013

de Freitas, S., \& Oliver, M. (2005). Does e - learning policy drive change in higher education? A case study relating models of organisational change to e - learning implementation. Journal of Higher Education Policy and Management, 27(1), 81-96. https://doi.org/10.1080/13600800500046255

Ertmer, P. A., \& Ottenbreit-Leftwich, A. T. (2010). Teacher technology change: How knowledge, confidence, beliefs, and culture intersect. Journal of Research on Technology in Education, 42(3), 255-284. https://doi.org/10.1080/15391523.2010.10782551

Fullan, M., \& Langworthy, M. (2013). Towards a new end: New pedagogies for deep learning [White paper]. Collaborative Impact.

Garrison, D. R., Anderson, T., \& Archer, W. (1999). Critical inquiry in a text-based environment: Computer conferencing in higher education. The Internet and Higher Education, 2(2-3), 87-105. https://doi.org/10.1016/S1096-7516(00)00016-6

GEM Report. (2020, April 16). Charlotte, a teacher from Marseille: "We're being asked to do a completely different job from before" [Web log]. Retrieved from https://gemreportunesco.wordpress.com/2020/04/16/charlotte-a-teacher-from-marseille-were-being-asked-t o-do-a-completely-different-job-from-before/

Giannini, S., \& Lewis, G. (2020, March 20). Three ways to plan for equity during the coronavirus school closures [Web $\quad \log ]$ Retrievd from https://gemreportunesco.wordpress.com/2020/03/25/three-ways-to-plan-for-equity-during-the-coronavirus-s chool-closures/

Guo, Z., Xiao, L., Van Toorn, C., Lai, Y., \& Seo, C. (2016). Promoting online learners' continuance intention: 
An integrated flow framework. Information \& Management, 53(2), $279-295$. https://doi.org/10.1016/j.im.2015.10.010

Kelehear, Z. (2020, April). Online teaching matters. Retrieved March 15, 2021, from http://hdl.handle.net/10675.2/623222

Kelly, J. L. Jr. (2011). A new interpretation of information rate. In L. C. MacLean, E. O. Thorp \& W. T. Ziemba (Eds.), The Kelly capital growth investment criterion: Theory and practice (pp. 25-34). World Scientific. https://doi.org/10.1142/9789814293501_0003

Kop, R., Fournier, H., \& Mak, J. S. F. (2011). A pedagogy of abundance or a pedagogy to support human beings? Participant support on massive open online courses. International Review of Research in Open and Distributed Learning, 12(7), 74-93. https://doi.org/10.19173/irrodl.v12i7.1041

Kozma, R. B. (2003). Technology and classroom practices: An international study. Journal of Research on Technology in Education, 36(1), 1-14. https://doi.org/10.1080/15391523.2003.10782399

Lipman, P. (1995). "Bringing out the best in them": The contribution of culturally relevant teachers to educational reform. Theory into Practice, 34(3), 202-208. https://doi.org/10.1080/00405849509543680

Libman, Z. (2013). Constructivism in education. In Z. Libman (Ed.), Learning, understanding, knowing: Exploring pathways to constructivist teaching (pp. 13-52). Hakibbutz Hameuchad, Mofet Institute [in Hebrew].

Manny-Ikan, I., Bashan, Z., \& Dahan, G. (2017). Evaluation of the program from routine to emergency - distance learning. Henrietta Szold Institution [in Hebrew]. Retrieved March 15, 2021, from https://www.szold.org.il/wp-content/uploads/2016/09/Pedagogia-1.pdf

Martin, F., Budhrani, K., Kumar, S., \& Ritzhaupt, A. (2019). Award-winning faculty online teaching practices: Roles and competencies. Online Learning, 23(1), 184-205. https://doi.org/10.24059/olj.v23i1.1329

McPherson, M., \& Nunes, M. B. (2004). The failure of a virtual social space (VSS) designed to create a learning community: Lessons learned. British Journal of Educational Technology, 35(3), 305-321. https://doi.org/10.1111/j.0007-1013.2004.00391.x

Mikropoulos, T. A., \& Natsis, A. (2011). Educational virtual environments: A ten-year review of empirical research (1999-2009). Computers \& Education, $\quad$ 56(3), https://doi.org/10.1016/j.compedu.2010.10.020

Miltiadou, M., \& Savenye, W. C. (2003). Applying social cognitive constructs of motivation to enhance student success in online distance education. AACE Journal, 11(1), 78-95. Retrieved March 14, 2021, from https:/www.learntechlib.org/primary/p/17795/

Mioduser, D., Nachmias, R., Forkosh-Baruch, A., \& Tubin, D. (2003). Educational innovation in ICT-integrating schools. School of Education, The Center for Science and Technology Education, Tel Aviv University [in Hebrew]. Retrieved March 15, 2021, from https://www.tau.ac.il/education/muse/ict/reportp1.doc

Moreno-Guerrero, A. J., Aznar-Díaz, I., Cáceres-Reche, P., \& Alonso-García, S. (2020). E-learning in the teaching of mathematics: an educational experience in adult high school. Mathematics, 8(5), 840. https://doi.org/10.3390/math8050840

National Authority for Measurement and Evaluation in Education [RAMA]. (2013). School external evaluation: National Meitzav reports-Meitzav 2013: Main findings [in Hebrew]. Retrieved March 16, 2021, from https://cms.education.gov.il/educationcms/units/rama/school_evaluation/dochotmaarachtim.htm

National Authority for Measurement and Evaluation in Education [RAMA]. (2020). Distance learning and learning during the Corona crisis-A survey of teachers and parents [in Hebrew]. Retrieved March 15, 2021, from https:/cms.education.gov.il/EducationCMS/Units/Rama/HaarachatProjectim/Remote_Learning_Reports.ht $\mathrm{m}$

Niwaz, A., Waqas, Q., \& Kamran, S. (2019). An exploration of issues and challenges faced by students in distance learning environment. Global Social Sciences Review, 4(4), 77-83. https://doi.org/10.31703/gssr.2019(IV-IV).11

OECD. (2013). 2013 innovation and research educational, environments learning Innovative. 
Oliveira, A., Feyzi, B. R., Ni, L., Mohsinah, A. A., Burgess, K. J., \& Guo, L. (2019). Emerging technologies as pedagogical tools for teaching and learning science: A literature review. Human Behavior and Emerging Technologies, 1(2), 149-160. https://doi.org/10.1002/hbe2.141

Reimers, F. M., \& Schleicher, A. (2020). A framework to guide an education response to the COVID-19 pandemic of 2020. OECD. Retrieved March 15, 2021, from https://globaled.gse.harvard.edu/files/geii/files/framework_guide_v1_002.pdf

Richardson, J. C., \& Swan, K. (2003). Examining social presence in online courses in relation to students' perceived learning and satisfaction. Journal of Asynchronous Learning Networks, 7(1), 68-88. https://doi.org/10.24059/olj.v7i1.1864

Salmon, G. (2003). E-moderating: The key to teaching and learning online (2nd ed.). Routledge Falmer. https://doi.org/10.4324/9780203465424

Schauble, L., Raghavan, K., \& Glaser, R. (1993). The discovery and reflection notation: A graphical trace for supporting self-regulation in computer-based laboratories. In S. P. Lajoie \& S. J. Derry (Eds.), Computers as cognitive tools (pp. 319-337). Hillsdale.

Schleicher, A. (2020, March 23). How can teachers and school systems respond to the COVID-19 pandemic? Some lessons from TALIS. Retrieved March 15, 2021, from https://oecdedutoday.com/how-teachers-school-systems-respond-coronavirus-talis/

Shachar, H. (2011). Constructive in education: Teaching, evaluation and research. Rechess [in Hebrew].

Shamir-Inbal, T., \& Avidov-Ungar, O. (2013). Empowerment patterns of leaders in ICT and school strengths following the implementation of national ICT reform. Journal of Information Technology Education: Research, 12, 141-158. https://doi.org/10.28945/1865

Sharma, S., Dick, G., Chin, W., \& Land, L. (2007). Self-regulation and e-learning (pp. 383-394). ECIS 2007 Proceedings. Retrieved March 15, 2021 from https://core.ac.uk/download/pdf/301350758.pdf

Shedroff, N. (2009). Design is the problem: The future of design must be sustainable. Rosenfeld Media.

Stöter, J., Bullen, M., Zawacki-Richter, O., \& von Prümmer, C. (2014). From the back door into the mainstream: The characteristics of lifelong learners. In O. Zawacki-Richter \& T. Anderson (Eds.), Online distance education: Towards a research agenda (pp. 421-458). AU Press. https://doi.org/10.15215/aupress/9781927356623.01

Tang, H., Wang, S., Qian, Y., \& Peck, K. L. (2016). Students' perceptions of the online instructors' roles in a massive open online course. In S. D'Agustino (Ed.), Creating teacher immediacy in online learning environments (pp. 273-289). IGI Global. https://doi.org/10.4018/978-1-4666-9995-3.ch014

Tovi, N. (2002). Computer aided teaching of the subject "energy transformation" and its influence on the students' achievements and standpoints. Unpublished master's thesis. Tel Aviv University, School of Education, Tel Aviv [in Hebrew].

Turuthi, D. G., Chemwei, B., \& Njagi, K. (2017). Effect of video mediated instruction on students' achievement, attitudes and motivation in larning Kiswahili proverbs in Kenya: A literature review. Kabarak Journal of Research and Innovation. Retrieved March 16, 2021, from https://africaneditors.org/journal/KJRI/full-text-pdf/90638-58556

Vaughan, N., \& Garrison, D. R. (2006). How blended learning can support a faculty development community of inquiry. Online Learning, 10(4), 139-152. https://doi.org/10.24059/olj.v10i4.1750

Vidislavsky, M., Peled, B., \& Pevsner, O. (2010). Adjusting schools to the 21st century. Eureka, 30. [in Hebrew]. Retrieved from https://www.matar.tau.ac.il/wp-content/uploads/2015/02/newspaper30-docs05.pdf

Vygotsky, L. (1978). Mind in society: The development of higher psychological processes. Harvard University Press.

Weissblei, E. (2020, June 1). Distance learning during the state of emergency due to the closure of education institutions because of the spread of coronavirus. Knesset Research and Information Center. [in Hebrew]. Retrieved March 16, 2021, from https://fs.knesset.gov.il/globaldocs/MMM/6c81656c-de69-ea11-8113-00155d0af32a/2_6c81656c-de69-ea1 1-8113-00155d0af32a_11_13919.pdf 
Weller, M. (2011). The digital scholar: How technology is transforming scholarly practice. Bloomsbury Academic. https://doi.org/10.5040/9781849666275

\section{Copyrights}

Copyright for this article is retained by the author, with first publication rights granted to the journal.

This is an open-access article distributed under the terms and conditions of the Creative Commons Attribution license (http://creativecommons.org/licenses/by/4.0/). 